\title{
Chapter 2 \\ Integrative Taxonomy of Birds: The Nature and Delimitation of Species
}

\author{
George Sangster
}

\begin{abstract}
Species are the basic currency in biodiversity studies, but what constitutes a species has long been controversial. Since the late 1990s, debates over species have shifted from theoretical questions (e.g., What is a species? Which species concept is best?) to empirical questions (How can we document species both efficiently and accurately?). A growing number of taxonomists agree that species can be discovered and documented in many different ways, preferably by employing and combining multiple types of evidence ("integrative taxonomy"). This chapter examines how and why avian taxonomy has become integrative, how species hypotheses are documented and falsified, and how the growth of taxonomic knowledge provides new and valuable insights into the speciation process, biogeography, and conservation biology.
\end{abstract}

Keywords Aves - Integrative taxonomy $\cdot$ Pluralism $\cdot$ Speciation $\cdot$ Species criteria $\cdot$ Species limits

\subsection{The Centrality of Species}

The concept of species is one of several key concepts in biology (Keller and Lloyd 1992; Pigliucci and Kaplan 2006; Sober 2006). While the discovery, description, and naming of species are strictly the responsibility of taxonomists, species are important in many other disciplines in society, including conservation (IUCN list of endangered species), health care (e.g., infectious diseases), and law (CITES, ESA; Geist 1992). Species are crucial for various concepts in other branches of biology, and society in general, as reflected by such terms as "keystone species" (ecology), "flagship species" (conservation), "speciation" (evolutionary biology), and "speciesism" (ethics). In biology the concept of species is shared across various hierarchies

\footnotetext{
G. Sangster $(\bowtie)$

Department of Bioinformatics and Genetics, Swedish Museum of Natural History, Stockholm, Sweden

Naturalis Biodiversity Center, Leiden, The Netherlands
} 
Table 2.1 Species are important in and shared among various hierarchies

\begin{tabular}{|c|c|c|c|}
\hline Ecology & Taxonomy $^{\mathrm{a}}$ & Genealogy & Conservation \\
\hline & Domain & & \\
\hline & Kingdom & & \\
\hline Ecosphere & Phylum & & \\
\hline Biome & Class & & \\
\hline Regional ecosystem & Order & & Landscape \\
\hline Local ecosystem & Family & Tree of life & Ecosystem (service) \\
\hline Community & Genus & Monophyletic group & Habitat \\
\hline Species & Species & Species & Species \\
\hline Population & Subspecies & Deme & ESU \\
\hline Organism & & Organism & Management unit \\
\hline Organ system & & Genome (germ line) & Population/breed \\
\hline Organ & & Gene & Genetic diversity \\
\hline Tissue & & & Adaptation \\
\hline Cell & & & Gene \\
\hline
\end{tabular}

${ }^{\mathrm{a}}$ See Dubois (2006) for a much more extensive set of categories

(Table 2.1). The broad relevance of species does not mean that the term species means the same thing to different biologists or that species taxa are uniform across groups. Far from it.

\subsection{Why Is There a Species Problem?}

There are numerous reasons why many professional biologists and philosophers have different opinions about "species." It is impossible to do justice to this rich debate in only a few paragraphs, so I will only briefly discuss the main points of contention. For the purpose of showing the diversity of opinion, I contrast the most divergent views, but it should be noted that there are numerous intermediate viewpoints.

\subsubsection{Monism vs. Pluralism}

A major issue among philosophers of science and more philosophically inclined systematists is the question whether species possess a single, unique quality that differentiates them from all other categories. Pluralists believe that there is no single unified way to delimit species; nature can be viewed from a multitude of perspectives which are equally valid. Most philosophers of science seem to agree that this is extremely likely and that pluralism is the only realistic approach. There are at least two brands of pluralism. One suggests that there are many permissible ways to classify 
species in any given situation, depending on the needs of the particular biologist (Kitcher 1984). Thus, ecologically defined species of ducks are just as acceptable as phylogenetically or morphologically defined species of ducks. The other suggests that in each group there is only one optimal classification, but that the optimal criteria to classify species may differ among groups (Mishler and Donoghue 1982).

The opposite view is monism, which holds that there is a single optimal way to divide nature into species. This is the view preferred by most biologists, because they would like to find the answer to the species problem and preferably have this derived from first principles in evolutionary biology or systematics (Ruse 1969; Pigliucci and Kaplan 2006).

\subsubsection{Realism vs. Anti-realism}

The issue of whether there is one or more than one valid way to classify species is closely related to the question of whether species taxa are real. Not surprisingly, monists (i.e., most biologists) tend to accept that species exist independent of our ability to recognize or find them. For instance, Mayr (1982) noted that variation is often discontinuous and that nature consists mostly of discrete units. Diamond (1966) demonstrated that members of "primitive" human tribes in New Guinea classify local birds in almost exactly the same way as professional taxonomists. Modern taxonomists may further point out that in many cases, different taxonomic methods identify the same species units, indicating that such species are not a fabric of the human mind.

Opponents of this view are not convinced by such observations and have argued that discrete groups are sometimes elusive, that all species are connected vertically through their ancestry, or that there is simply nothing special about species. The view that species are not real, i.e., that they have no objective reality outside of the human mind, is also called "nominalism" (Stamos 2003). Modern-day adherents to this view typically come from a background in either botany (where species limits tend to be more blurred by gene flow than in zoology) or paleontology (where inferring species limits through time has always been considered difficult). Botanist Van Valen (1976), for instance, noted that the classification of oaks is so problematic as a result of gene flow that it is impossible to find any discrete species. He asked "why can't there be taxa without species?" In his presidential address to the Paleontological Society, Shaw (1969) argued that species are not real (and should be abandoned), because drawing species limits in time is completely arbitrary. Mishler (1999) emphasized that all taxonomic ranks are arbitrary, but that clades are real. He argued that in a truly phylogenetic system, there is no place for ranks and as a consequence, no place for species. In his view, species are phylogenetic groups just like higher taxa, and all other putative properties of the species rank that have been proposed by various taxonomists (phenetic groupings, interbreeding, reticulation) can also be found at other ranks or are inconsistent with phylogenetic groups. 


\subsubsection{Theoretical vs. Operational}

Philosophers of science have proposed several theoretical "solutions" to the species problem. These include the idea that "species are individuals" (Ghiselin 1974) or that "species are relations" (Stamos 2003). However, these do not connect with taxonomic practice. The Hennigian species concept, which proposes that species can be delimited in time by branching events (nodes) and extinction events (Hennig 1966), has also been proposed as a solution (Ridley 1989) but fails for the same reason. A formal description of this species concept (Kornet 1993) is mathematically sound, is universally applicable, and is able to assign every individual organism to a species. Yet, this method is hopelessly unrealistic because one needs to know the position of every individual within the genealogy.

At the other end of the spectrum is the phenetic school, which is completely theory-free (Sokal and Crovello 1970). However, without any theoretical underpinnings, it is impossible to determine which of many methods to group individuals into "species" is the best. The phylogenetic species concept defines species as "the smallest diagnosable cluster of individual organisms within which there is a parental pattern of ancestry and descent" (Cracraft 1983) but does not tell what those species are beyond the somewhat vague "evolutionary units."

It is safe to say that theoretical concepts are usually not very strong operationally and that operational concepts do not tend to be strong theoretically (Hull 1997, 1999). Both aspects are connected, because in order to know how one should find species, one must first know what to look for. Whereas many biologists would agree with Cracraft (2000) that a species concept "should work," no species concept is entirely satisfactory without a solid theoretical basis.

\subsubsection{Pattern vs. Process}

Some species concepts emphasize evolutionary mechanisms and processes, such as mate choice, species recognition, interbreeding, hybridization, and gene flow, whereas others focus on the results and patterns of evolution (such as diagnosability, monophyly, and congruency). The biological and recognition concepts are examples of process-based species concepts, whereas phylogenetic, monophyletic, and internodal concepts are pattern-based approaches. Evolutionary biologists and population geneticists tend to prefer process-based species concepts, whereas taxonomists and phylogeneticists tend to prefer pattern-based approaches. 


\subsubsection{Prospective vs. Historical}

Under the biological species concept, taxa are recognized as species, if they remain "reproductively isolated," in the sense that they do not fuse into a single population (Mayr 1982, 1996). The BSC, therefore, is prospective (O'Hara 1993, 1994; Maddison 1997); only future events will show whether currently recognized taxa remain reproductively isolated or fuse into each other.

The alternative viewpoint is that species-level taxa should be delimited on the basis of historical subdivisions (i.e., historical patterns), rather than present-day or possible future interactions and processes (Lidén and Oxelman 1989), such as hybridization and gene flow. Maddison (1997) argued that species concepts which are prospective and which require speculations about the future are not helpful in biology; since all of our data are of the present and past, the units by which we interpret these data must also be strictly historical. There are two major kinds of historical units: species as clades and species as lineages. The species-as-clades view was developed by Donoghue (1985) and de Queiroz and Donoghue (1988, 1990) and considers phylogenetic species to be the smallest monophyletic groups of organisms supported by autapomorphies (unique derived character states). The species-as-lineages view regards species as (parts of) branches in a phylogeny (Mayden 1997; de Queiroz 1998, 1999).

\subsubsection{Concerns by End Users}

Some end users of species have been very vocal about how taxonomists should delimit species. For instance, some conservationists and biodiversity scientists have complained that if pattern-based species concepts were to be implemented widely, the number of species would become "too high" (e.g., Agapow et al. 2004) and result in "pseudoreplication" of species (Isaac et al. 2004). Other complaints made by some end users of taxonomy are (1) that taxonomists have recognized species on the basis of "trivial" morphological character differences or molecular differences (Collar 1997; Tobias et al. 2010), (2) that taxonomy has become "unstable" due to the use of phylogenetic species concepts (Isaac et al. 2004; Mace 2004), and (3) that species designations no longer correspond to genetically incompatible populations (affecting captive breeding and reintroductions; Frankham et al. 2012). These are not scientific (i.e., empirical) concerns, but they do illustrate what some end users have come to expect from species.

All these viewpoints underscore the many dimensions of the species problem. An important insight was that the species problem actually comprises several distinct problems (e.g., Frost and Kluge 1994; Reydon 2004): What are species? How do species originate? How can, may, or should one delimit species in practice? It seems obvious that one should have a good sense of what species are before one can tell 
how species originate or how to delimit species. Thus, the concept of species is the primary problem. This set the stage for a major breakthrough in the late 1990s.

\subsection{The Lineage Concept}

The lineage concept of species was first articulated by Simpson (1951) and further developed by Hennig (1966), Wiley (1978), and Wilson (1995). These authors viewed species as branches in the tree of life. This view was long known as the "evolutionary species concept" or "Hennigian species concept." Because these views were not accompanied by, and did not easily translate into, operational criteria, these have long been ignored by taxonomists (but see Frost and Hillis 1990). The idea that species are best seen as lineages gained strong support in the late 1990s due to three now-classic publications by Richard Mayden and Kevin de Queiroz (Mayden 1997; de Queiroz 1998, 1999). Their case rested on two important insights.

First, there is a fundamental distinction between the species concept (primary species concept, Mayden 1997), which tells us what species are, and species criteria (secondary species concepts, Mayden 1997), which describe how species taxa may be delimited in practice. Both Mayden and de Queiroz observed that most species concepts are actually little more than prescriptions of how species should be delimited (i.e., species criteria). Thus, many "species concepts" have confounded operational and theoretical aspects of species and have defined the items to be discovered by the discovery process (Frost and Kluge 1994).

Second, most views on species and species criteria are consistent with the idea that species are segments of population lineages (de Queiroz 1998, 1999), i.e., branches or parts of branches in the tree of life. Although some criteria can only be applied at one time-slice (e.g., reproductive isolation), it does not follow that species are only real at that point in time, and this does not preclude one from seeing such species as lineages.

\subsection{Corollaries of the Lineage Concept}

The lineage concept does not by itself dictate how species should be delimited, but it provides a few important hints. First, because different species may have different properties, all traditional species criteria are potentially relevant for finding species. Importantly, different species criteria highlight different aspects of species. Thus, it makes sense to apply as many criteria as possible, not only to avoid overlooking species but also to describe and better understand the nature of these species taxa (Sangster 2014).

Second, there is no reason to presume that all the properties identified by traditional species concepts evolve in all lineages, let alone all at the same time. Thus, a species may exist even if it does not possess one's preferred species criterion 
Fig. 2.1 Different species properties (e.g., reproductive isolation, diagnosability, monophyly, ecological niches) may evolve at different times during divergence. The absence of a particular property (e.g., property 4) does not falsify species rank, if there is other evidence that it is a separate lineage (e.g., properties 1-3)

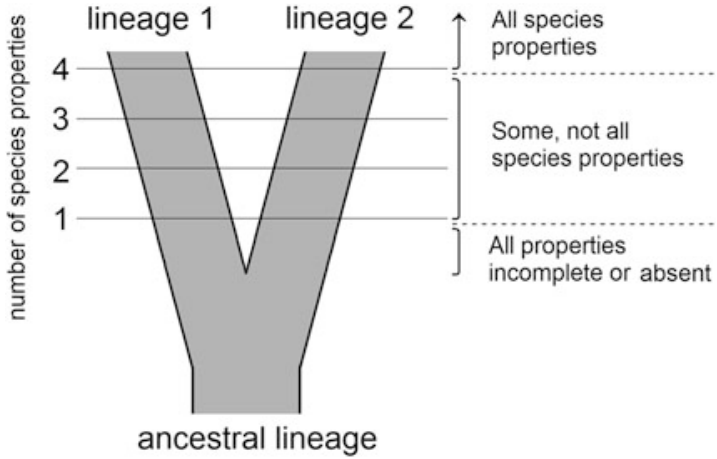

(Fig. 2.1). The absence of a particular species property does not mean that the lineage itself does not exist. This is an important observation, because from this it follows that no property can be considered “defining” for species (de Queiroz 1999, 2007). This explicitly rejects the equality of species; some may possess all properties, others may not; some may be highly distinctive, others are cryptic; some may be monophyletic in a gene tree, whereas others are not; some may be reproductively isolated, but others may not.

Third, if species are lineages, then the species delimited by taxonomists are hypotheses of lineages. Thus, species are not simply described ("facts"), but their existence is a testable hypothesis. Like any other scientific statement, these should be documented as thoroughly as possible.

\subsection{Integrative Taxonomy}

Integrative taxonomy may be considered the operational counterpart of the lineage concept. The term "integrative taxonomy" was introduced almost simultaneously in two papers which appeared in 2005 (Dayrat 2005; Will et al. 2005). Both papers emphasized that it is important to combine and integrate multiple approaches to species delimitation. Will et al.'s (2005) motivation for their paper was to provide a critique of barcoding, which is the use of a single line of molecular evidence to identify and discover species. Ironically, it later became apparent that barcoding may also be a valid part of integrative taxonomy, because it may produce new hypotheses of species taxa, which may be tested, refined, falsified, or corroborated by other evidence (Padial and de la Riva 2007). 


\subsubsection{Why Multiple Data?}

Seeking multiple lines of evidence to document species taxa is a logical consequence of the view that species taxa are hypotheses. Indeed, it is common sense that a hypothesis is better confirmed by different kinds of evidence than by more evidence of the same kind. It also can be rationalized from Bayesian principles. Each time a hypothesis is confirmed by the same kind of evidence (e.g., morphology), the probability expressing the degree of belief that it will do so in the future gradually increases. On the other hand, the prior probability that a hypothesis is confirmed by another type of evidence (e.g., reproductive isolation) may initially be quite low. Therefore, finding that the hypothesis is confirmed by a new line of evidence represents a significant increase in the probability that the hypothesis is true (Chalmers 1999). The validity of questionable species taxa based on small numbers of specimens or small numbers of characters is often addressed with other datasets, typically molecular data (e.g., Bensch and Pearson 2002; Sangster et al. 2016a; Pérez-Emán et al. 2018). Another reason why it is best to seek multiple kinds of evidence is that all taxonomic criteria have both strengths and weaknesses (Table 2.2).

\subsubsection{Why Integrate?}

Although the use of multiple lines of evidence in taxonomy is not new, the emphasis on integration of evidence is novel. Collecting multiple kinds of evidence is not enough, for several reasons. As noted above, various species criteria are complementary, because these highlight different aspects of lineage divergence. Sometimes the interpretation of one type of evidence depends on information on other properties. For instance, to demonstrate that two putative sympatric species are reproductively isolated, it is often necessary to demonstrate that these species are diagnosable or reciprocally monophyletic. Evidence for species may be scattered across various papers and thus should be collected and assessed together. Thus, integrative taxonomy may be defined as the theory and practice of documenting and evaluating hypotheses about the taxonomic status of putative species by integrating multiple lines of evidence.

\subsection{Strengths of Integrative Taxonomy}

By combining and integrating taxonomic evidence in a single approach, integrative taxonomy has several qualities that distinguish it from traditional approaches.

First, if one views different kinds of taxonomic data as complementary accounts of species divergence, it becomes apparent that many taxonomic conflicts are not based on incompatible interpretations of species limits but simply stem from 
Table 2.2 Strengths and drawbacks of various species criteria

\begin{tabular}{|c|c|c|}
\hline Criterion & Strengths & Drawbacks \\
\hline $\begin{array}{l}\text { Diagnosability } \\
\text { (fixed difference in } \\
\text { heritable character) }\end{array}$ & $\begin{array}{l}\text { Easy to apply } \\
\text { Cost-effective } \\
\text { Applicable to a broad range of taxa } \\
\text { Applicable to a broad range of data } \\
\text { types } \\
\text { Can be expressed in statistical } \\
\text { terms (e.g., Wiens and Servedio } \\
2000)\end{array}$ & $\begin{array}{l}\text { Heritability often unknown } \\
\text { Sample size dependent } \\
\text { Nonheritable differences may also } \\
\text { identify evolutionary units (e.g., } \\
\text { song, biometric differences) } \\
\text { Difficult to apply to sequence data }\end{array}$ \\
\hline $\begin{array}{l}\text { Degree of } \\
\text { difference } \\
\text { (phenotypic/genetic } \\
\text { divergence) }\end{array}$ & $\begin{array}{l}\text { Phenotypic divergence: appeals to } \\
\text { the wish for "good species," pop- } \\
\text { ular among end-users of taxonomy } \\
\text { Genetic divergence: easily } \\
\text { obtained as by-product of phylo- } \\
\text { genetic analysis }\end{array}$ & $\begin{array}{l}\text { Requires a better supported } \\
\text { reference taxonomy (Sangster } \\
\text { 2000) } \\
\text { Cutoff point typically arbitrary } \\
\text { Difficult to apply in complex } \\
\text { taxonomic problems } \\
\text { May conflict with phylogenetic } \\
\text { relationships }\end{array}$ \\
\hline $\begin{array}{l}\text { Reproductive } \\
\text { isolation (intrinsic } \\
\text { barriers to gene } \\
\text { flow) }\end{array}$ & $\begin{array}{l}\text { Often point of no return (perma- } \\
\text { nent lineage divergence) } \\
\text { Mechanism of maintenance of } \\
\text { species boundaries }\end{array}$ & $\begin{array}{l}\text { Limited scope: cannot be applied } \\
\text { directly in allopatry, at different } \\
\text { time slices, or in paleontology } \\
\text { Requires prediction of future inter- } \\
\text { actions } \\
\text { Ability to interbreed is } \\
\text { plesiomorphic: reproductive com- } \\
\text { patibility may conflict with phylo- } \\
\text { genetic relationships } \\
\text { Arbitrary: many species hybridize; } \\
\text { when are species (not) } \\
\text { reproductively isolated? } \\
\text { Degree of gene flow/isolation may } \\
\text { differ among genes }\end{array}$ \\
\hline Prezygotic isolation & $\begin{array}{l}\text { Biological meaning ("species } \\
\text { recognition") }\end{array}$ & $\begin{array}{l}\text { Recognition or cues may be } \\
\text { dependent on environment, phase of } \\
\text { breeding season } \\
\text { Density dependance: degree of } \\
\text { interbreeding may depend on the } \\
\text { availability of homospecific } \\
\text { partners (Hubbs' rule) }\end{array}$ \\
\hline Postzygotic isolation & $\begin{array}{l}\text { Biological meaning (“genetic } \\
\text { incompatibility") }\end{array}$ & $\begin{array}{l}\text { Extremely hard to document } \\
\text { Application beyond expertise of } \\
\text { most trained taxonomists } \\
\text { Fitness of hybrids and/or parental } \\
\text { species may vary with local } \\
\text { circumstances (e.g., bounded hybrid } \\
\text { superiority; Moore 1977) }\end{array}$ \\
\hline Non-monophyly & Removes nonhistorical units & $\begin{array}{l}\text { Only a suitable basis for splitting if } \\
\text { two taxa are not sisters (other } \\
\text { evidence is required if the two } \\
\text { "species" are nested) }\end{array}$ \\
\hline
\end{tabular}


Table 2.2 (continued)

\begin{tabular}{l|l|l}
\hline Criterion & Strengths & Drawbacks \\
\hline $\begin{array}{l}\text { Reciprocal } \\
\text { monophyly (of gene } \\
\text { trees) }\end{array}$ & $\begin{array}{l}\text { Demonstration of historical isola- } \\
\text { tion } \\
\text { Easy to apply }\end{array}$ & $\begin{array}{l}\text { Cannot be used in isolation (mono- } \\
\text { phyletic groups exist at many levels, } \\
\text { so further evidence is required) } \\
\text { Evolves slowly, thus prone to type } \\
\text { II errors } \\
\text { Choice of loci is arbitrary } \\
\text { Monophyly may be based on } \\
\text { chance, rather than historical } \\
\text { isolation (Irwin 2002) }\end{array}$ \\
& & \\
\hline
\end{tabular}

differences in the sensitivity of taxonomic criteria. For instance, the finding that two diagnosable species do not form reciprocally monophyletic groups does not represent a major taxonomic dilemma but is best interpreted as a case where one property (diagnosability of morphological character states) simply became fixed before the other (exclusive coalescence of gene trees). Thus, integrative taxonomy may lay numerous taxonomic controversies to rest.

Second, integrative taxonomy is an efficient approach to taxonomy. Because evidence for species rank is not limited to one ("defining") property, integrative taxonomy may be informed by all kinds of available data.

Third, the integration of different kinds of evidence may help to discover additional species. Evidence which is not very relevant or informative in isolation may be crucial when combined with other evidence. For instance, the finding that two migratory subspecies of Bean Goose Anser fabalis have overlapping wintering ranges in Western Europe is not remarkable nor is their return to different breeding areas in Siberia (Burgers et al. 1991). However, when combined with the knowledge that high-latitude species of waterfowl find their mates on the wintering grounds, these findings become very significant for taxonomy. If pair formation takes place on the wintering grounds, then both forms have the opportunity to form mixed pairs. If no birds ringed in winter return in the breeding area of the other form, then this is prima facie evidence that the two are not forming mixed pairs and remain reproductively isolated (Sangster and Oreel 1996). This hypothesis received some further support from the findings that both groups formed separate groups in a molecular phylogeographic analysis (Ruokonen et al. 2008) and may not even be each other's closest relatives (Ottenburghs et al. 2016).

Fourth, examples such as these highlight the fundamentally analytic and iterative nature of integrative taxonomy and underscore that species delimitation is a science (Yeates et al. 2011; Sluys 2013). Thus, modern taxonomy is more than a mere baptismal act or a one-time "description." Hypotheses of species rank require documentation and reassessment in the light of new evidence, just like any other scientific hypothesis.

Finally, by including all species criteria under a single unified approach, integrative taxonomy shifts away attention from the yes-or-no question of whether or not 
Table 2.3 Examples of falsifications of species limits based on defining criteria

\begin{tabular}{l|l|l}
\hline Species pair & $\begin{array}{l}\text { Original hypothesis of species } \\
\text { distinctiveness based on: }\end{array}$ & $\begin{array}{l}\text { Proposed falsification of } \\
\text { species status based on: }\end{array}$ \\
\hline $\begin{array}{l}\text { Ducks: Anas } \\
\text { carolinensis }-A . \\
\text { crecca }\end{array}$ & $\begin{array}{l}\text { Non-sister group relationship } \\
\text { (paraphyly with respect to } \\
\text { A. flavirostris) } \\
\text { High level of sequence divergence } \\
\text { (mtDNA) } \\
\text { Diagnostic differences in male plum- } \\
\text { age (Sangster et al. 2001) }\end{array}$ & $\begin{array}{l}\text { Inferred gene flow of nuclear } \\
\text { DNA (Peters et al. 2012) }\end{array}$ \\
\hline $\begin{array}{l}\text { Giant petrels: } \\
\text { giganteus }\end{array}$ & $\begin{array}{l}\text { Sympatric (allochronic) breeding } \\
\text { Plumage and bare parts (diagnostic } \\
\text { differences; Bourne and Warham } \\
\text { 1966) }\end{array}$ & $\begin{array}{l}\text { Low genetic divergence } \\
\text { (<1\%; Penhallurick and Wink } \\
\text { 2004) }\end{array}$ \\
\hline $\begin{array}{l}\text { Kites: Milvus } \\
\text { fasciicauda-M. milvus }\end{array}$ & $\begin{array}{l}\text { Plumage (diagnostic differences; } \\
\text { Hazevoet 1995) }\end{array}$ & $\begin{array}{l}\text { Non-monophyly of } \\
\text { cytochrome b sequences } \\
\text { (Johnson et al. 2005) }\end{array}$ \\
\hline $\begin{array}{l}\text { Owls: Otus } \\
\text { madagascariensis-O. } \\
\text { rutilus }\end{array}$ & $\begin{array}{l}\text { Plumage and vocalizations (diagnos- } \\
\text { tic differences, Rasmussen et al. } \\
\text { 2000) }\end{array}$ & $\begin{array}{l}\text { Non-monophyly of ND2 } \\
\text { sequences (Fuchs et al. 2007) }\end{array}$ \\
\hline
\end{tabular}

species A meets the criterion of species concept $\mathrm{X}$ but instead focuses on the information content of the total body of evidence.

\subsection{What Is Not Integrative Taxonomy?}

Many types of data, analyses, and criteria can be valid parts of integrative taxonomy, but this is not to say that anything goes in integrative taxonomy. At least two approaches are inconsistent with integrative taxonomy: (1) the falsification of species rank by invoking a "defining" criterion and (2) the use of a set of "standard" criteria that restricts the scope of taxonomic fact-finding.

\subsubsection{Falsification by a "Defining" Species Criterion}

Species taxa may show many different combinations of species properties, and not every property may be present in each species (Fig. 2.1). Thus, it is important to keep in mind that while any particular species property may help to document the existence of a species, its absence in other species does not falsify their species rank (de Queiroz 2007). From this, it follows that a hypothesis about the validity of a species taxon can only be falsified if all lines of evidence supporting that taxon are falsified. Unfortunately, this is sometimes overlooked. Table 2.3 lists several recent instances where a "defining" criterion was used to falsify species that had been 
recognized on the basis of other evidence. In each of these cases, the authors have added new data but have inappropriately placed that evidence above all previous evidence. Some authors have used this strategy to draw far-reaching but highly dubious conclusions. For instance, Johnson et al. (2005) suggested that the Cape Verde Kite Milvus fasciicauda "does not exist," because cytochrome $b$ sequences of that species were nested phylogenetically within those of the Red Kite M. milvus. This ignores not only that these species are still diagnosable by plumage characters (Hazevoet 1995) but also that non-monophyly may simply result from incomplete lineage sorting due to recent speciation-a common phenomenon in bird species (reviewed by Funk and Omland 2003; McKay and Zink 2010) of which new examples are still being discovered (Päckert et al. 2012; Luna et al. 2017). Appeals to defining criteria will no doubt continue to be made in the taxonomic literature but should be resisted, because it results in unnecessary confusion and instability. This is especially true, if defining criteria differ from paper to paper (as suggested by Table 2.3).

\subsubsection{Standardization of Species Criteria}

A recent proposal attempted to standardize the assessment of species limits by limiting this process to a small number of data classes and a few characters per class (Tobias et al. 2010). This set of criteria explicitly excluded entire data classes that are commonly used in taxonomy (molecular data, phylogenetic data, multivariate analyses, and detailed evidence from hybrid zones). The approach put forward by Tobias et al. (2010) seems to be rooted in what philosophers of science call "anti-realism": the merit of the criteria is defined in terms of their generality and simplicity, not in terms of whether these result in the delimitation of real evolutionary units. This is underscored by the taxonomic revisions that resulted from application of these criteria (del Hoyo and Collar 2014, 2016), which include several species that modern molecular phylogenetic studies have documented as paraphyletic assemblages of multiple distinct taxa (e.g., Golden-fronted Woodpecker Melanerpes aurifrons, Red-crowned Parakeet Cyanoramphus novaezelandiae, Mourning Wheatear Oenanthe lugens; see Kearvell et al. 2003; Schweizer and Shirihai 2013; García-Trejo et al. 2009; Rawlence et al. 2015). The criteria put forward by Tobias et al. (2010) are inappropriate, because the lineages that we call "species" are things that we discover, not create. Taxonomy is a fact-finding endeavor; any practice that limits, distorts, or interferes with this endeavor should be abandoned.

Attempts to falsify species taxa by appeal to a particular defining criterion and pleas to standardize species taxonomy by limiting its scope can be viewed as attempts to prescribe how species must be found, so that any species not found by that method is not a species. The flaws of this approach may be illustrated by analogy to a criminal court case. Taxonomy and the criminal justice process share many similarities owing to the fact that both strongly rely on empirical data (Table 2.4). Like a criminal court case, the task of species taxonomy is to assess objectively what 
Table 2.4 Similarities between the empirical aspects of species-level taxonomy (evaluating species limits) and the criminal justice process (evaluating guilt)

\begin{tabular}{|c|c|c|c|}
\hline Aspect & General principle & $\begin{array}{l}\text { Taxonomy (species } \\
\text { limits) }\end{array}$ & Criminal justice (guilt) \\
\hline Aim & $\begin{array}{l}\text { Assess objectively } \\
\text { what has happened }\end{array}$ & $\begin{array}{l}\text { Speciation (has } \\
\text { speciation occurred?) }\end{array}$ & $\begin{array}{l}\text { Crime (did this suspect } \\
\text { commit this crime?) }\end{array}$ \\
\hline Hypotheses & $\begin{array}{l}\text { The null hypothesis } \\
\text { should be accepted } \\
\text { unless sufficient } \\
\text { evidence shows this to } \\
\text { be false }\end{array}$ & $\begin{array}{l}\mathrm{H}_{0}: \text { no lineage } \\
\text { separation has occurred } \\
\text { (taxa must not be } \\
\text { recognized as species) } \\
\mathrm{H}_{1}: \text { speciation has } \\
\text { occurred (taxa are best } \\
\text { treated as species) }\end{array}$ & $\begin{array}{l}\mathrm{H}_{0} \text { : defendant is } \\
\text { innocent (and must be } \\
\text { acquitted) } \\
\mathrm{H}_{1} \text { : defendant } \\
\text { committed the crime }\end{array}$ \\
\hline Strategy & $\begin{array}{l}\text { Document the best } \\
\text { explanation for the } \\
\text { observed evidence; } \\
\text { rule out alternatives }\end{array}$ & $\begin{array}{l}\text { (1) Collect as much evi- } \\
\text { dence and as many types } \\
\text { of evidence as possible; } \\
\text { (2) integrate evidence; } \\
\text { (3) define scenarios; } \\
\text { (4) evaluate and com- } \\
\text { pare the evidence for all } \\
\text { plausible scenarios; } \\
\text { repeat, if necessary }\end{array}$ & Idem \\
\hline Evidence & $\begin{array}{l}\text { Reliance on empirical } \\
\text { data }\end{array}$ & $\begin{array}{l}\text { Examples: morphology, } \\
\text { genetics, bioacoustics, } \\
\text { behavior }\end{array}$ & $\begin{array}{l}\text { Examples: eye witness } \\
\text { testimony, DNA fin- } \\
\text { gerprinting, examina- } \\
\text { tion of physical objects, } \\
\text { written confession }\end{array}$ \\
\hline $\begin{array}{l}\text { Quality } \\
\text { assessment }\end{array}$ & $\begin{array}{l}\text { Assessment of quality } \\
\text { (meaning) of the } \\
\text { evidence }\end{array}$ & $\begin{array}{l}\text { Examples: rule out } \\
\text { misidentification } \\
\text { (of specimens), contam- } \\
\text { ination (of DNA sam- } \\
\text { ples), inappropriate } \\
\text { methodology, effects of } \\
\text { small sample size or } \\
\text { poor reference data, } \\
\text { comparison among } \\
\text { non-homological char- } \\
\text { acter states }\end{array}$ & $\begin{array}{l}\text { Examples: rule out } \\
\text { misidentification } \\
\text { (of people or objects), } \\
\text { contamination (of DNA } \\
\text { samples), inappropriate } \\
\text { methodology, effects of } \\
\text { small sample size or } \\
\text { poor reference data }\end{array}$ \\
\hline $\begin{array}{l}\text { Complementarity } \\
\text { of evidence }\end{array}$ & $\begin{array}{l}\text { Multiple evidence is } \\
\text { good; multiple inde- } \\
\text { pendent lines of evi- } \\
\text { dence is even better }\end{array}$ & $\begin{array}{l}\text { Example: finding a } \\
\text { diagnostic bioacoustic } \\
\text { character state plus } \\
\text { reciprocal monophyly of } \\
\text { DNA is more convinc- } \\
\text { ing evidence for lineage } \\
\text { separation than finding } \\
\text { two diagnostic bio- } \\
\text { acoustic character states }\end{array}$ & $\begin{array}{l}\text { Example: two credible } \\
\text { witnesses saying the } \\
\text { same thing is good, but } \\
\text { a single credible } \\
\text { witness plus DNA } \\
\text { evidence is even better }\end{array}$ \\
\hline $\begin{array}{l}\text { Integration of } \\
\text { evidence }\end{array}$ & $\begin{array}{l}\text { Different lines of } \\
\text { evidence highlight }\end{array}$ & $\begin{array}{l}\text { Example: bioacoustic } \\
\text { data may show a pattern }\end{array}$ & $\begin{array}{l}\text { Example: an eye wit- } \\
\text { ness may describe what }\end{array}$ \\
\hline
\end{tabular}


Table 2.4 (continued)

\begin{tabular}{|c|c|c|c|}
\hline Aspect & General principle & $\begin{array}{l}\text { Taxonomy (species } \\
\text { limits) }\end{array}$ & Criminal justice (guilt) \\
\hline & $\begin{array}{l}\text { different aspects; } \\
\text { must be integrated }\end{array}$ & $\begin{array}{l}\text { (consistent differences } \\
\text { in songs), playback tests } \\
\text { may highlight lack of } \\
\text { mate recognition, DNA } \\
\text { data may show the result } \\
\text { (lack of gene flow) (see } \\
\text { also Table 2.2) }\end{array}$ & $\begin{array}{l}\text { happened, whereas } \\
\text { DNA may tie the } \\
\text { defendant to the crime } \\
\text { scene }\end{array}$ \\
\hline Uniqueness & $\begin{array}{l}\text { Each species/criminal } \\
\text { court case is unique }\end{array}$ & $\begin{array}{l}\text { No single type of evi- } \\
\text { dence (or combination } \\
\text { thereof) can be assumed } \\
\text { to "work" in every case }\end{array}$ & Idem \\
\hline
\end{tabular}

has happened at some time in the past. In both cases, a hypothesis must be documented, and alternative hypotheses must be excluded. Those who assess and evaluate the hypothesis did not witness the relevant events and thus have to rely on evidence. Needless to say, the more evidence the better. Having multiple types of evidence is better than having more of the same type of evidence. If multiple kinds of evidence tell the same story, this increases the plausibility of the hypothesis. Speciation (like a criminal act) may have been a complex, protracted process, and therefore multiple types of evidence may be useful to highlight various aspects of this process. In many cases, these lines of evidence are complementary and must be integrated. In addition, each pair of species (just like each crime) is unique in one way or another, and there is no a priori reason to suspect that a single type of evidence works in all cases. Finally, like a criminal court case, taxonomy is an iterative process. When important new evidence emerges, the original hypothesis must be evaluated again within the light of all available evidence. To argue which species criterion should be adopted as the defining criterion in taxonomy is just as futile as arguing which single type of evidence should be used to "define" guilt in all criminal court cases. Any attempt to a priori limit the evidence used to evaluate a taxonomic case study interferes with the fundamentally empirical nature of taxonomy.

\subsection{The Dynamics of Taxonomic Change}

After the official start of zoological nomenclature in 1758, the number of bird species recognized by taxonomists increased steadily until reaching a peak in the early twentieth century (Fig. 2.2). During the 1840s, zoologists Carl Sundevall and Herman Schlegel began to treat poorly defined species as geographical races 
A

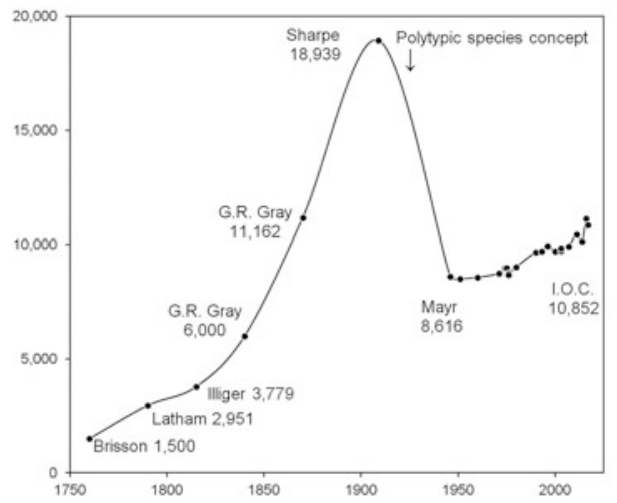

B

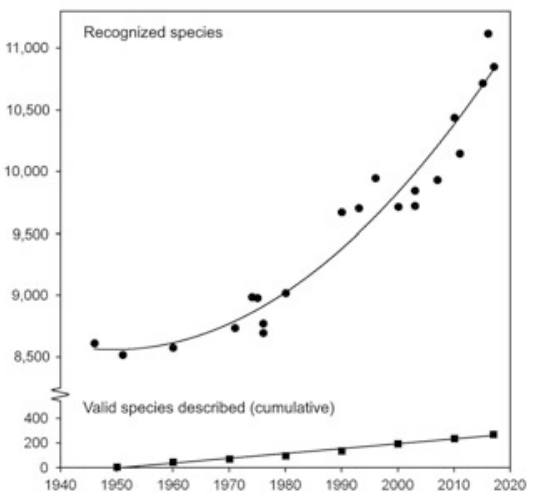

Fig. 2.2 (a) Trends of the total number of recognized species of recent birds from 1760 to 2017. Note the dramatic $(>50 \%)$ reduction in the number of recognized species between 1909 (Sharpe) and 1946 (Mayr) and the relatively slow increase since 1946 (Updated from Haffer 1992). (b) Trends of the total number of recognized species of recent birds (upper panel, based on various estimates and classifications, as indicated by the filled circles) and newly described species of birds (lower panel) from 1946 to 2016. Note that the number of recognized species increases much faster (c. 92 species per year in 2007-2017) than the number of newly described valid species (c. 5.3 per year). A second-order trend line was added to illustrate the trend (Updated from Sangster and Luksenburg 2015)

(subspecies). In subsequent decades, increased exploration and collection of specimens led to improved understanding of the geographic and morphological continuity of previously recognized species. In the second half of the nineteenth century, a growing number of zoological works started ranking taxa as subspecies (Stejneger 1884). During this period, intergradation became the cornerstone of subspecific taxonomy (Allen 1871). According to this view, subspecies are distinguishable forms that intergrade, whereas species do not intergrade (Stejneger 1884). Because the criterion of intergradation can only be applied to geographically contiguous (i.e., continental) populations, taxonomists used an arbitrary assessment of the degree of difference to rank island populations (Stone 1899).

By the early twentieth century, the recognition of subspecies had degraded to the principle of "geographic representation." Many thousands of distinctive and less distinctive taxa were combined in large polytypic species simply based on the non-overlap of their breeding ranges. The inclusion of subspecies into polytypic species was seen as a simplification of taxonomy, because it reduced the number of recognized species (Stejneger 1884; Mayr 1942). The effect on the number of bird species was substantial: within about 40 years, the number of recognized species had dropped from 18,939 (Sharpe 1909) to 8590 (Mayr and Amadon 1951).

By the mid-twentieth century, the number of bird species started to increase again, and this trend is accelerating (Fig. 2.2b). Increases of species numbers have also been documented in other vertebrates, but the rate of the increase differs among groups (Fig. 2.3). For instance, the number of extant bird species increased by $0.9 \%$ 

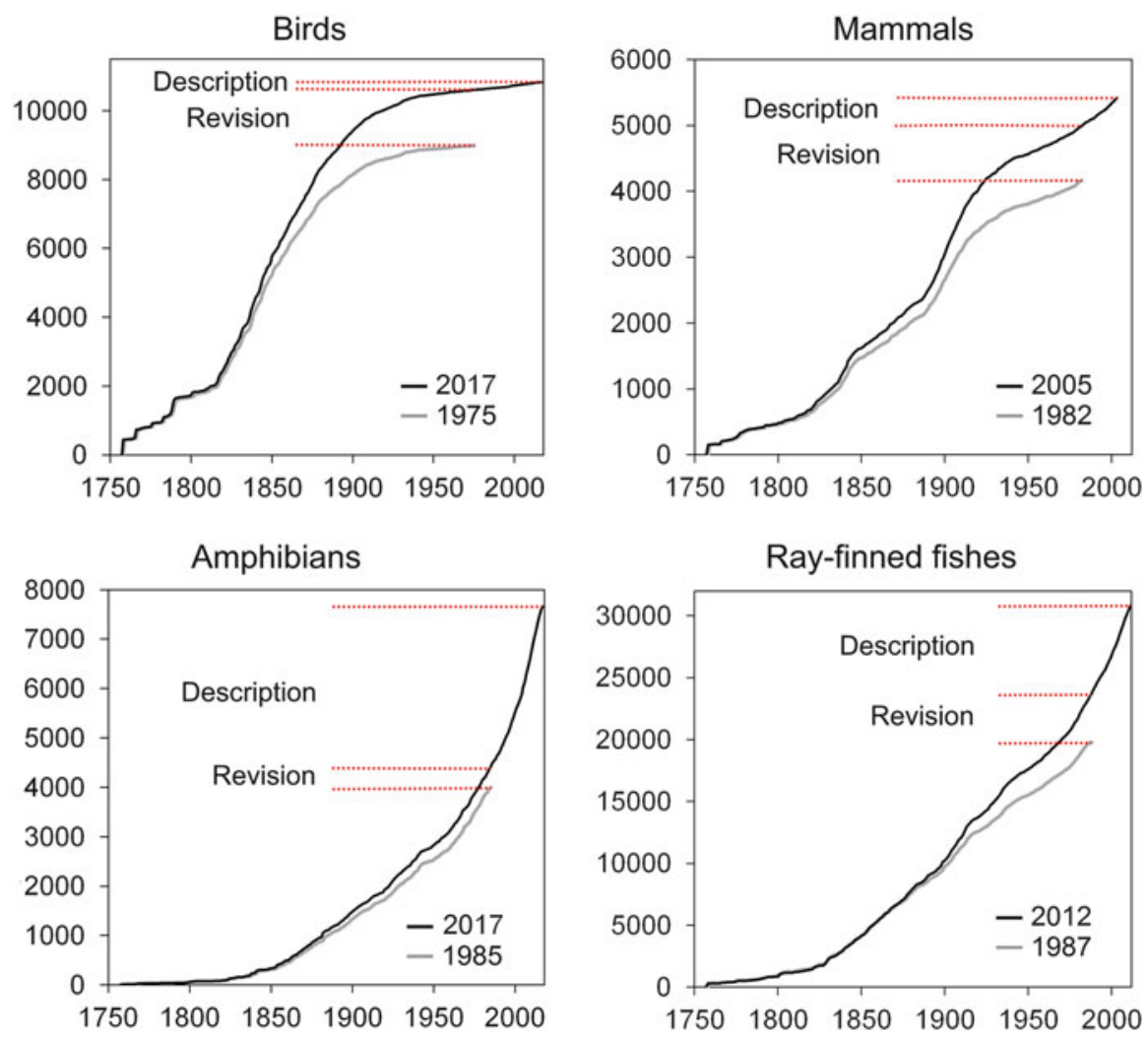

Fig. 2.3 Cumulative numbers of species of birds, mammals, amphibians, and ray-finned fishes recognized in classifications published in 1975-1987 (gray lines) and 2005-2012 (black lines). The relative contributions of taxonomic description (new species) and taxonomic revision (subspecies upgraded to species rank) differ greatly among vertebrate groups, with revisions predominating in birds and mammals and descriptions predominating in ray-finned Fishes and especially amphibians

per year during 2007-2016, whereas in amphibians the increase was a whopping $2.4 \%$ per year.

\subsection{The Drivers of Taxonomic Change}

Why does the number of bird species keep rising even after more than 250 years of taxonomic research? Three major reasons have been proposed for the increasing number of vertebrates recognized by specialists: (1) new discoveries, (2) revisions based on new empirical evidence (e.g., molecular data), and (3) revisions based on changes of the way species are delimited. Hanken (1999) attributed the increase of the number of amphibian species to all three of these, whereas Isaac et al. (2004) 
A

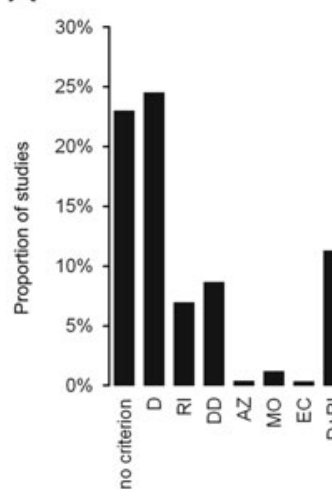

B

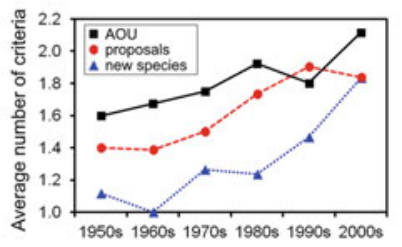

Fig. 2.4 (a) Species criteria used in a dataset of 1249 taxonomic studies (new descriptions, revisions, and recommendations made by the AOU Committee on Classification and Nomenclature) published between 1950 and 2009 (Sangster 2014). Note the large number of different combinations of criteria, illustrating the eclectic nature of species-level taxonomy in birds. $D$ diagnosability, $R I$ reproductive isolation, $D D$ degree of difference, $A Z$ adaptive zone, $M O$ monophyly, $E C$ exclusive coalescence of gene trees. (b) Changes in the average number of criteria per taxonomic hypothesis, illustrating the increasingly pluralistic nature of species delimitation (Modified from Sangster 2014)

incorrectly attributed the rising number of recognized species of birds and mammals to a shift toward the phylogenetic species concept (see below).

The relative role of descriptions and revisions in the increasing number of species is easily inferred by comparing plots of the cumulative number of species described over time of a recent classification with that of a less-recent classification (Fig. 2.3). These show that in birds, revisions play a much greater role in the increase than descriptions, whereas the opposite is true in amphibians (Fig. 2.3). More specifically, of the c. 92 species of birds that on average were added each year during 2007-2016, only about five per year were newly described species (Fig. 2.2b).

Analyses of the taxonomic literature have shown that the rising number of bird species cannot be attributed to a shift toward the phylogenetic species concept (Sangster 2009). The trend to recognize more species of birds started at least two decades before the introduction of the phylogenetic species concept, and most newly recognized species were not based exclusively on criteria associated with that concept (Sangster 2009). In a set of 747 taxonomic proposals published in major ornithological journals, about $85 \%$ of the newly proposed species were supported by new taxonomic data. Thus, in birds taxonomic revision is the predominant proximate driver of the growing number of species, and revisions are very often based on new empirical data.

Taxonomic practice is pluralistic (employing multiple types of evidence and criteria) and increasingly eclectic (employing many different combinations of criteria). Using a dataset of $>1200$ studies, a recent study found that six taxonomic criteria were applied in $>30$ unique combinations (Fig. 2.4; Sangster 2014). Avian 
taxonomists apply different criteria as complementary rather than as rival approaches to species delimitation, which is consistent with the general lineage concept of species and with the methodological framework of integrative taxonomy (Sangster 2014). Another positive trend is that the information content of taxonomic studies is increasing; taxonomists write longer papers, use more characters and more specimens, make comparisons with more taxa, and make greater use of illustrations, sonagrams, and maps (Sangster and Luksenburg 2015). There is evidence that this promotes stability: more elaborate descriptions require fewer subsequent revisions (Sangster and Luksenburg 2015).

The great magnitude of the lumping process during the first half of the twentieth century and the nearly complete lack of empirical evidence that supported these revisions are important reasons why the taxonomy of birds is still in flux. Taxonomic changes since the 1950s have a strong empirical basis and thus mark progress. Furthermore, because numbers of recognized species of birds are increasing exponentially (Fig. 2.2b) and many bird species have not been revised since the early twentieth century, species inventories of birds are still far from complete.

\subsection{Benefits of Integrative Taxonomy to Other Fields}

\subsubsection{Speciation Studies}

The processes by which new evolutionary lineages diversify may be highly complex and may differ among species. Identifying the main processes involved in speciation typically requires in-depth study from multiple angles. Research questions asked in speciation research are often identical to those that taxonomists ask (e.g., In which ways do the populations differ from each other? What is their population structure? When did the populations diverge? Do members of these populations recognize each other as potential mates/competitors? Is there any hybridization and does this lead to gene flow?). Modern taxonomic studies are crucial for speciation research, because one must first document patterns of variation before one can identify and understand the processes responsible for these patterns. Indeed, many interesting case studies in speciation research recently have been identified from integrative taxonomic research, as the following examples illustrate.

The black Carrion Crow Corvus corone and gray-and-black Hooded Crow $C$. cornix have long been treated as subspecies, because they meet and hybridize along a narrow contact zone in central Europe and Scotland. A series of modern studies in their hybrid zone showed that the crows actually behave as species (reviewed by Parkin et al. 2003). Further research on mitochondrial and nuclear DNA divergence found almost no divergence at the DNA level (Haring et al. 2007, 2012; Wolf et al. 2010), indicating either very recent speciation or widespread gene flow or both. Building on this work, full-genome studies demonstrated that the Carrion and Hooded Crows indeed show widespread gene flow in large parts of their genome, but not in the genes responsible for mate choice (preference for 
"black" vs. "gray-and-black" phenotypes) and plumage type. Both sets of genes are located rather close to each other and occupy a $<2$-megabase stretch of DNA (Poelstra et al. 2014). This shows that speciation may result from changes in a relatively small and local part of the genome. In turn, this finding is relevant for taxonomy, because it shows that gene flow does not necessarily falsify species rank and that traditional molecular methods (mtDNA and a few ncDNA markers) may not suffice to find all lineages.

Similarly, the discovery that two populations of Oceanodroma storm petrels in the Azores (Portugal) most likely originated through sympatric speciation by allochrony (Friesen et al. 2007) was preceded by a series of taxonomic studies which documented various aspects of their divergence. Storm petrels breeding during the summer (hot season) and those breeding during winter (cold season) were first found to show differences in morphology and timing of molt (Monteiro and Furness 1998). This was followed by studies which showed that these populations also differ by vocalizations, response to playback, and mtDNA and microsatellites but are more closely related to each other than to any other storm petrel (Bolton 2007; Friesen et al. 2007; Smith et al. 2007). The combined data provided compelling evidence that hot- and cold-season storm petrel populations arose sympatrically (Friesen et al. 2007). This represented the first evidence for sympatric speciation by allochrony in tetrapods.

Hybrid speciation is another rare form of speciation. Based on the descriptive taxonomic works of Meise (1936) and Johnston (1969), Italian Sparrow Passer italiae had long been suspected to be a hybrid species resulting from past interbreeding between Spanish $P$. hispaniolensis and House Sparrows $P$. domesticus. This was corroborated by recent work on morphology, microsatellites, and mitochondrial and nuclear DNA sequences (Elgvin et al. 2011; Hermansen et al. 2011, 2014; Trier et al. 2014). Conversely, these studies have helped clarify the taxonomic status of Italian Sparrow, which is now treated as a full species (Sangster et al. 2015).

\subsubsection{Biogeography}

Biogeography, the science that attempts to document and understand spatial patterns in biology, is one of the primary components of systematic research. Taxonomy (including phylogenetic study) provides the scientific basis for historical biogeography. Refinement of taxonomic designations results in increased precision in biogeographic studies. For instance, modern phylogeographic and taxonomic studies (Ribas et al. 2011; Fernandes et al. 2014) have not only corroborated the existence of multiple areas of endemism in the Amazon region of South America (Cracraft 1985) but also contributed to the designation of a new area of endemism northwest of Manaus, Brazil (Borges and da Silva 2012). Similarly, the importance of the whitesand forests of the northern Peruvian Amazon was only recently recognized due to the discovery of several new species confined to this habitat (Whitney and Alvarez Alonso 1998, 2005; Alvarez Alonso and Whitney 2001; Isler et al. 2002). 
Contact zones have long been of interest for biogeographers, because these may help identify which ecological and historical factors have influenced the past and present distributions of populations and their divergence (Swenson 2010). Recent taxonomic studies have revealed several previously overlooked contact zones between morphologically similar taxa. Examples include the geese Branta canadensis/hutchinsii in Arctic North America (Paxinos et al. 2002), the pittas Erythropitta macklotii/habenichti in New Guinea (Irestedt et al. 2013), and the grey shrikes Lanius excubitor/borealis in Western Siberia (Olsson et al. 2010).

The processes responsible for high tropical species richness have attracted much debate, but with little consensus so far. For instance, it has been proposed that speciation rates in the tropics are higher or that extinction rates are lower or that clades originate in the tropics but only recently spread to higher latitudes leaving little time for species richness to accumulate in temperate zones (Pianka 1966; Rahbek and Graves 2001; Willig et al. 2003; Weir and Schluter 2007). Adequate, unbiased inventories of the diversity at different latitudes are an important first step in distinguishing among these and many other explanations. Recent phylogenetic and taxonomic research suggests that species diversity has been underestimated especially in the tropics (Lohman et al. 2010; Milá et al. 2012; Voelker et al. 2013), and this has bearing on some of the explanations that have been proposed for latitudinal diversity gradients (e.g., Tobias et al. 2008; Irestedt et al. 2013). Recognition of more species in the tropics results in steeper latitudinal gradients, but also in shorter branch lengths, suggesting more recent speciation (Irestedt et al. 2013).

\subsubsection{Conservation}

Taxonomy provides the scientific underpinnings of biodiversity conservation (Wheeler and Cracraft 1997; Cotterill et al. 2017). There are at least three major ways in which conservation work benefits from continued taxonomic research. First, the discovery and documentation of species lineages represents a crucial first step in biodiversity conservation, because species are often considered the basic currency in conservation (e.g., IUCN Red List). By documenting previously overlooked species and removing invalid species, taxonomic research helps conservationists prioritize their work. Threatened species which had remained hidden due to incorrect taxonomy are still being documented even in supposedly well-known parts of the world (Fig. 2.5), underscoring the urgency of taxonomic work.

Second, taxonomic research helps to delimit Endemic Bird Areas which are an efficient way to identify conservation priorities for restricted-range species (Stattersfield et al. 1998). An Endemic Bird Area is an area which encompasses the overlapping breeding range of at least two species that have a range of $<50,000 \mathrm{~km}^{2}$. Two examples of Endemic Bird Areas recently identified by taxonomic research are the Balearic Islands and Corsica. Until the mid-1990s, only one endemic species was recognized (Corsican Nuthatch Sitta whiteheadi), but subsequent taxonomic study has added two endemic species to the Balearic Islands (Balearic Shearwater Puffinus 


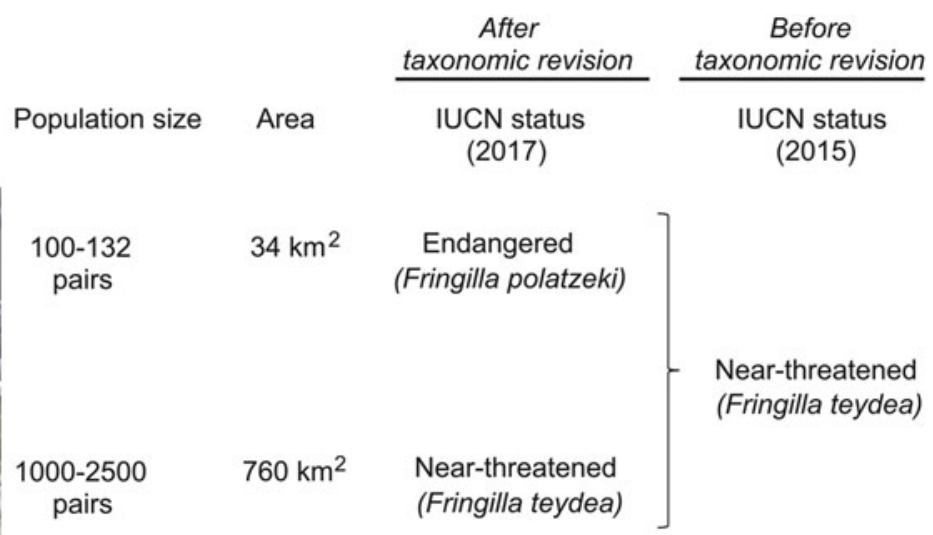

Fig. 2.5 Taxonomic revision affects the recognition of threatened species. The Blue Chaffinch Fringilla teydea was long considered a polytypic species with two subspecies, F. t. polatzeki on Gran Canaria and F.t. teydea on Tenerife. Until 2016, Blue Chaffinch was classified as a "nearthreatened" species, because the range size and population numbers of the Tenerife taxon (now F. teydea) overwhelmed those of the much rarer Gran Canaria taxon (now F. polatzeki). After two studies showed that the two taxa differed in plumage, morphometrics, vocalizations, response to playback, sperm morphology, and nuclear DNA (Lifjeld et al. 2016; Sangster et al. 2016b), $F$. polatzeki was classified as an endangered species. Photographs courtesy of Jolanda A. Luksenburg (upper) and Ian Merrill (lower)

mauretanicus and Balearic Warbler Sylvia balearica), one to Corsica (Corsican Finch Carduelis corsicana), and two which are shared between the two areas and parts of mainland Italy (Moltoni's Warbler Sylvia subalpina and Mediterranean Flycatcher Muscicapa tyrrhenica) (Sangster 2000; Shirihai et al. 2001; Sangster et al. 2002; Brambilla et al. 2008; Förschler et al. 2009; Pons et al. 2016).

Finally, taxonomic revisions help identify the lineages that contain most evolutionary history, which is an important measure for prioritizing conservation efforts (e.g., Vane-Wright et al. 1991; Mooers and Atkins 2003). Using metrics that capture the evolutionary distinctiveness and conservation status of species, Jetz et al. (2014) identified the top-ranking bird species for phylogenetic conservation measures. Several of these represent species that have only recently been revealed by taxonomic study, including North Island Brown Kiwi Apteryx mantelli (Burbidge et al. 2003), Udzungwa Forest Partridge Xenoperdix udzungwensis (Dinesen et al. 1994), Australian Painted-snipe Rostratula australis (Baker et al. 2007), and New Zealand Storm Petrel Fregetta maoriana (Robertson et al. 2011). 


\subsection{Remaining Issues}

Integrative taxonomy is an active field, and it is likely that various aspects will be further clarified and developed in the near future (Padial et al. 2010; Schlick-Steiner et al. 2010). Among the issues that remain to be clarified are the following:

As noted before, one of the arguments for integrative taxonomy is that different kinds of evidence highlight different aspects of species divergence: the tempo of divergence, frequency of hybridization, adaptation, and the geography and mechanisms of speciation. But this also means that there will be more and more cases of discordance among different kinds of evidence. How should one deal with discordance? The most sensitive methods may not be the most accurate methods. On which grounds does one decide which hypothesis is most likely correct? Should one err on the side of recognizing too few or too many species (e.g., Carstens et al. 2013)?

Continued progress in taxonomy depends largely on the collection of new empirical data (including specimens, sound recordings, and DNA sequences). Obtaining sufficient data may be problematic in several cases, such as (1) recent speciation when many markers may not be sensitive enough to detect divergence, (2) in paleontology when data are typically limited to bone material, and (3) when species are known from very few specimens (e.g., singletons; Lim et al. 2012). Finding efficient ways to maximize confidence in taxonomic hypotheses will remain a major challenge.

Acknowledgments I am grateful to Jolanda Luksenburg and Ian Merrill for the permission to use their photographs of Blue Chaffinches. I was supported by grants from Mark Constantine and the Swedish Research Council (grant 2015-06455).

\section{References}

Agapow P-M, Bininda-Emonds ORP, Crandall KA, Gittleman JL, Mace GM, Marshall JC, Purvis A (2004) The impact of species concept on biodiversity studies. Q Rev Biol 79:161-179. https://doi. org/10.1086/383542

Allen JA (1871) On the mammals and winter birds of East Florida. Bull Mus Comp Zool II (3): $161-450$

Alvarez Alonso J, Whitney BM (2001) A new Zimmerius tyrannulet (Aves: Tyrannidae) from white sand forests of northern Amazonian Peru. Wilson Bull 113:1-9. https://doi.org/10.1676/00435643(2001)113[0001:ANZTAT]2.0.CO;2

Baker AJ, Pereira SL, Rogers DI, Elbourne R, Hassell CJ (2007) Mitochondrial-DNA evidence shows the Australian Painted Snipe is a full species, Rostratula australis. Emu 107:185-189. https://doi.org/10.1071/MU07024

Bensch S, Pearson D (2002) The large-billed Reed Warbler Acrocephalus orinus revisited. Ibis 144:259-267. https://doi.org/10.1046/j.1474-919X.2002.00036.x

Bolton M (2007) Playback experiments indicate absence of vocal recognition among temporally and geographically separated populations of Madeiran Storm-petrels Oceanodroma castro. Ibis 149:255-265. https://doi.org/10.1111/j.1474-919X.2006.00624.x 
Borges SH, da Silva JMC (2012) A new area of endemism for Amazonian birds in the Rio Negro Basin. Wilson J Ornithol 124:15-23. https://doi.org/10.1676/07-103.1

Bourne WRP, Warham J (1966) Geographical variation in the giant petrels of the genus Macronectes. Ardea 54:45-67

Brambilla M, Vitulano S, Spina F, Baccetti N, Gargallo G, Fabbri E, Guidali F, Randi E (2008) A molecular phylogeny of the Sylvia cantillans complex: cryptic species within the Mediterranean basin. Mol Phylogenet Evol 48:461-472. https://doi.org/10.1016/j.ympev.2008.05.013

Burbidge ML, Colbourne RG, Robertson HA, Baker AJ (2003) Molecular and other biological evidence supports the recognition of at least three species of brown kiwi. Conserv Genet 4:167-177. https://doi.org/10.1023/A:1023386506067

Burgers J, Smit JJ, van der Voet H (1991) Origins and systematics of two types of the Bean Goose Anser fabalis (Latham, 1787) wintering in the Netherlands. Ardea 79:307-316

Carstens BC, Pelletier TA, Reid NM, Satler JD (2013) How to fail at species delimitation. Mol Ecol 22:4369-4383. https://doi.org/10.1111/mec.12413

Chalmers AF (1999) What is this thing called science? 3rd edn. Open University Press, Maidenhead

Collar NJ (1997) Taxonomy and conservation: chicken and egg. Bull Br Ornithol Club 117:122-136

Cotterill FP, Groves CP, Taylor PJ (2017) Taxonomy: refine rather than stabilize. Nature 547:162. https://doi.org/10.1038/547162d

Cracraft J (1983) Species concepts and speciation analysis. Curr Ornithol 3:159-187

Cracraft J (1985) Historical biogeography and patterns of differentiation within the South American avifauna: areas of endemism. Ornithol Monogr (36):49-84

Cracraft J (2000) Species concepts in theoretical and applied biology: a systematic debate with consequences. In: Wheeler QD, Meier R (eds) Species concepts and phylogenetic theory: a debate. Columbia University Press, New York, pp 3-14

Dayrat B (2005) Towards integrative taxonomy. Biol J Linn Soc 85:407-415. https://doi.org/10. 1111/j.1095-8312.2005.00503.x

de Queiroz K (1998) The general lineage concept of species, species criteria, and the process of speciation: a conceptual unification and terminological recommendations. In: Howard DJ, Berlocher SH (eds) Endless forms: species and speciation. Oxford University Press, Oxford, pp 57-75

de Queiroz K (1999) The general lineage concept of species and the defining properties of the species category. In: Wilson RA (ed) Species: new interdisciplinary essays. MIT Press, Cambridge, pp 49-89 [a highly influential description of the general lineage concept of species]

de Queiroz K (2007) Species concepts and species delimitation. Syst Biol 56:879-886. https://doi. org/10.1080/10635150701701083

de Queiroz K, Donoghue MJ (1988) Phylogenetic systematics and the species problem. Cladistics 4:317-338. https://doi.org/10.1111/j.1096-0031.1988.tb00518.x

de Queiroz K, Donoghue MJ (1990) Phylogenetic systematics and species revisited. Cladistics 6:83-90. https://doi.org/10.1111/j.1096-0031.1990.tb00527.x

del Hoyo J, Collar NJ (2014) Illustrated checklist of the birds of the world, vol 1. Lynx Edicions, Barcelona

del Hoyo J, Collar NJ (2016) Illustrated checklist of the birds of the world, vol 2. Lynx Edicions, Barcelona

Diamond J (1966) Zoological classification system of a primitive people. Science 151:1102-1104. https://doi.org/10.1126/science.151.3714.1102

Dinesen L, Lehmberg T, Svendsen JO, Hansen LA, Fjeldså J (1994) A new genus and species of perdicine bird (Phasianidae, Perdicini) from Tanzania; a relict form with Indo-Malayan affinities. Ibis 136:2-11. https://doi.org/10.1111/j.1474-919X.1994.tb08125.x

Donoghue MJ (1985) A critique of the biological species concept and recommendations for a phylogenetic alternative. Bryologist 88:172-181. https://doi.org/10.2307/3243026

Dubois A (2006) Proposed rules for the incorporation of nomina of higher-ranked zoological taxa in the International Code of Zoological Nomenclature. 2. The proposed rules and their rationale. Zoosystema 28:165-258 
Elgvin TO, Hermansen JS, Fijarczyk A, Bonnet T, Borge T, Sæther SA, Voje KL, Sætre G-P (2011) Hybrid speciation in sparrows II: a role for sex chromosomes? Mol Ecol 20:3823-3837. https://doi. org/10.1111/j.1365-294X.2011.05182.x

Fernandes AM, Wink M, Sardelli CH, Aleixo A (2014) Multiple speciation across the Andes and throughout Amazonia: the case of the spot-backed antbird species complex (Hylophylax naevius/Hylophylax naevioides). J Biogeogr 41:1094-1104. https://doi.org/10.1111/jbi.12277

Förschler MI, Senar JC, Perret P, Björklund M (2009) The species status of the Corsican finch Carduelis corsicana assessed by three genetic markers with different rates of evolution. Mol Phylogenet Evol 52:234-240. https://doi.org/10.1016/j.ympev.2009.02.014

Frankham R, Ballou JD, Dudash MR, Eldridge MDB, Fenster CB, Lacy RC, Mendelson JR, Porton IJ, Ralls K, Ryder AO (2012) Implications of different species concepts for conserving biodiversity. Biol Conserv 153:25-31. https://doi.org/10.1016/j.biocon.2012.04.034

Friesen VL, Smith AL, Gómez-Díaz E, Bolton M, Furness RW, González-Solís J, Monteiro LR (2007) Sympatric speciation by allochrony in a seabird. Proc Natl Acad Sci 104:18589-18594. https://doi.org/10.1073/pnas.0700446104

Frost DR, Hillis DM (1990) Species in concept and practice. Herpetologica 46:87-104

Frost DR, Kluge AG (1994) A consideration of epistemiology in systematic biology, with special reference to species. Cladistics 10:259-294. https://doi.org/10.1111/j.1096-0031.1994.tb00178.x

Fuchs J, Pons J-M, Pasquet E, Raherilalao MJ, Goodman SM (2007) Geographical structure of genetic variation in the Malagasy Scops-owl inferred from mitochondrial sequence data. Condor 109:408-418. https://doi.org/10.1650/0010-5422(2007)109[408:GSOGVI]2.0.CO;2

Funk DJ, Omland KE (2003) Species-level paraphyly and polyphyly: frequency, causes, and consequences, with insights from animal mitochondrial DNA. Annu Rev Ecol Evol Syst 34:397-423. https://doi.org/10.1146/annurev.ecolsys.34.011802.132421

García-Trejo EA, Espinosa De Los Monteros A, Del Coro Arizmendi M, Navarro-Siüenza AG (2009) Molecular systematics of the Red-bellied and Golden-fronted Woodpeckers. Condor 111:442-452. https://doi.org/10.1525/cond.2009.080017

Geist V (1992) Endangered species and the law. Nature 357:274-276

Ghiselin MT (1974) A radical solution to the species problem. Syst Zool 23:536-544. https://doi. org/10.1093/sysbio/23.4.536

Haffer J (1992) The history of species concepts and species limits in ornithology. Bull Br Ornithol Club Centenary Suppl 112A:107-158

Hanken J (1999) Why are there so many new amphibian species when amphibians are declining. Trends Ecol Evol 14:7-8. https://doi.org/10.1016/S0169-5347(98)01534-1

Haring E, Gamauf A, Kryukov A (2007) Phylogeographic patterns in widespread corvid birds. Mol Phylogenet Evol 45:840-862. https://doi.org/10.1016/j.ympev.2007.06.016

Haring E, Däubl B, Pinsker W, Kryukov A, Gamauf A (2012) Genetic divergences and intraspecific variation in corvids of the genus Corvus (Aves: Passeriformes: Corvidae) - a first survey based on museum specimens. J Zool Syst Evol Res 50:230-246. https://doi.org/10.1111/j.1439-0469. 2012.00664.x

Hazevoet CJ (1995) The birds of the Cape Verde Islands. BOU Check-list No. 13. BOU, Tring

Hennig W (1966) Phylogenetic systematics. University Illinois Press, Urbana

Hermansen JS, Sæther SA, Elgvin TO, Borge T, Hjelle E, Sætre G-P (2011) Hybrid speciation in sparrows I: phenotypic intermediacy, genetic admixture and barriers to gene flow. Mol Ecol 20:3812-3822. https://doi.org/10.1111/j.1365-294X.2011.05183.x

Hermansen JS, Haas F, Trier CN, Bailey RI, Nederbragt AJ, Marzal A, Sætre G-P (2014) Hybrid speciation through sorting of parental incompatibilities in Italian sparrows. Mol Ecol 23:5831-5842. https://doi.org/10.1111/mec. 12910

Hull DL (1997) The ideal species concept-and why we can't get it. In: Claridge MF, Dawah HA, Wilson MR (eds) Species, the units of biodiversity. Systematics Association Special Volume 54. Chapman and Hall, London, pp 357-380

Hull DL (1999) On the plurality of species: questioning the party line. In: Wilson RA (ed) Species: new interdisciplinary essays. MIT Press, Cambridge, pp 23-48

Irestedt M, Fabre P-H, Batalha-Filho H, Jønsson KA, Roselaar CS, Sangster G, Ericson PGP (2013) The spatio-temporal colonization and diversification across the Indo-Pacific by a 'great 
speciator' (Aves, Erythropitta erythrogaster). Proc R Soc Lond B 280:20130309. https://doi. org/10.1098/rspb.2013.0309

Irwin DE (2002) Phylogeographic breaks without geographic barriers to gene flow. Evolution 56:2383-2394. https://doi.org/10.1554/0014-3820(2002)056[2383:PBWGBT]2.0.CO;2

Isaac NJB, Mallet J, Mace GM (2004) Taxonomic inflation: its influence on macroecology and conservation. Trends Ecol Evol 19:464-469. https://doi.org/10.1016/j.tree.2004.06.004

Isler ML, Alvarez Alonso J, Isler PR, Valqui T, Begazo A, Whitney BM (2002) Rediscovery of a cryptic species and description of a new subspecies in the Myrmeciza hemimelaena complex (Thamnophilidae) of the Neotropics. Auk 119:362-378. https://doi.org/10.1642/0004-8038 (2002)119[0362:ROACSA]2.0.CO;2

Jetz W, Thomas GH, Joy JB, Redding DW, Hartmann K, Mooers AO (2014) Global distribution and conservation of evolutionary distinctness in birds. Curr Biol 24:919-930. https://doi.org/10. 1016/j.cub.2014.03.011

Johnson JA, Watson RT, Mindell DP (2005) Prioritizing species conservation: does the Cape Verde kite exist? Proc R Soc Lond B 272:1365-1371. https://doi.org/10.1098/rspb.2005.3098

Johnston RF (1969) Taxonomy of house sparrows in the Mediterranean basin. Condor 71:129-139. https://doi.org/10.2307/1366074

Kearvell JC, Grant AD, Boon WM (2003) The orange-fronted parakeet (Cyanoramphus malherbi) is a distinct species: a review of recent research into its taxonomy and systematic relationship within the genus Cyanoramphus. Notornis 50:27-35

Keller EF, Lloyd EA (eds) (1992) Keywords in evolutionary biology. Harvard University Press, Cambridge

Kitcher P (1984) Species. Philos Sci 51:308-333. https://doi.org/10.1086/289182

Kornet DJ (1993) Permanent splits as speciation events: a formal reconstruction of the internodal species concept. J Theor Biol 164:407-435. https://doi.org/10.1006/jtbi.1993.1164

Lidén M, Oxelman B (1989) Species-pattern or process? Taxon 38:228-232. https://doi.org/10. 2307/1220837

Lifjeld JT, Anmarkrud JA, Calabuig P, Cooper JE, Johannessen LE, Johnsen A, Kearns AM, Lachlan RF, Laskemoen T, Marthinsen G, Stensrud E, Garcia-del-Rey E (2016) Species-level divergences in multiple functional traits between the two endemic subspecies of Blue Chaffinches Fringilla teydea in Canary Islands. BMC Zool 1(1):4. https://doi.org/10.1186/s40850-016-0008-4

Lim GS, Balke M, Meier R (2012) Determining species boundaries in a world full of rarity: singletons, species delimitation methods. Syst Biol 61:165-169. https://doi.org/10.1093/ sysbio/syr030

Lohman DJ, Ingram KG, Prawiradilaga DM, Winker K, Sheldon FH, Moyle RG, Ng PKL, Ong PS, Wang LK, Braile TM, Astuti D, Meier R (2010) Cryptic genetic diversity in "widespread" Southeast Asian bird species suggests that Philippine avian endemism is gravely underestimated. Biol Conserv 143:1885-1890. https://doi.org/10.1016/j.biocon.2010.04.042

Luna LW, Souza TO, Carneiro LS, Silva WAG, Schneider H, Sampaio I, Araripe J, Rêgo PSD (2017) Molecular data and distribution dynamics indicate a recent and incomplete separation of manakins species of the genus Antilophia (Aves: Pipridae) in response to Holocene climate change. J Avian Biol 48:1177-1188. https://doi.org/10.1111/jav.01378

Mace GM (2004) The role of taxonomy in species conservation. Philos Trans R Soc Lond B 359:711-719. https://doi.org/10.1098/rstb.2003.1454

Maddison WP (1997) Gene trees in species trees. Syst Biol 46:523-536. https://doi.org/10.1093/ sysbio/46.3.523

Mayden RL (1997) A hierarchy of species concepts: the denouement in the saga of the species problem. In: Claridge MF, Dawah HA, Wilson MR (eds) Species, the units of biodiversity. Systematics Association Special Volume 54. Chapman and Hall, London, pp 381-424

Mayr E (1942) Systematics and the origin of species. Columbia University Press, New York

Mayr E (1982) The growth of biological thought. Harvard University Press, Cambridge

Mayr E (1996) What is a species, and what is not? Philos Sci 63:262-277. https://doi.org/10.1086/ 289912 
Mayr E, Amadon D (1951) A classification of recent birds. Am Mus Novit 1496:1-42

McKay BD, Zink RM (2010) The causes of mitochondrial DNA gene tree paraphyly in birds. Mol Phylogenet Evol 54:647-650. https://doi.org/10.1016/j.ympev.2009.08.024

Meise W (1936) Zur Systematik und Verbreitungsgeschichte der Haus- und Weidensperlinge, Passer domesticus (L.) und hispaniolensis (T.). J Ornithol 84:631-672. https://doi.org/10. 1007/BF01951015

Milá B, Tavares ES, Muñoz Saldaña A, Karubian J, Smith TB, Baker AJ (2012) A trans-Amazonian screening of mtDNA reveals deep intraspecific divergence in forest birds and suggests a vast underestimation of species diversity. PLoS One 7(7):e40541. https://doi.org/10.1371/journal. pone. 0040541

Mishler BD (1999) Getting rid of species? In: Wilson RA (ed) Species: new interdisciplinary essays. MIT Press, Cambridge, pp 307-315

Mishler BD, Donoghue MJ (1982) Species concepts: a case for pluralism. Syst Zool 31:491-503. https://doi.org/10.2307/2413371

Monteiro LR, Furness RW (1998) Speciation through temporal segregation of Madeiran Storm-petrel (Oceanodroma castro) populations in the Azores? Philos Trans R Soc Lond B 353:945-953. https://doi.org/10.1098/rstb.1998.0259

Mooers AØ, Atkins RA (2003) Indonesia's threatened birds: over 500 million years of evolutionary heritage at risk. Anim Conserv 6:183-188. https://doi.org/10.1017/S1367943003003226

Moore WS (1977) An evaluation of narrow hybrid zones in vertebrates. Q Rev Biol 52:263-277. https://doi.org/10.1086/409995

O'Hara RJ (1993) Systematic generalization, historical fate and the species problem. Syst Biol 42:231-246. https://doi.org/10.1093/sysbio/42.3.231

O'Hara RJ (1994) Evolutionary history and the species problem. Am Zool 34:12-22. https://doi. org/10.1093/icb/34.1.12

Olsson U, Alström P, Svensson L, Aliabadian M, Sundberg P (2010) The Lanius excubitor (Aves, Passeriformes) conundrum-Taxonomic dilemma when molecular and non-molecular data tell different stories. Mol Phylogenet Evol 55:347-357. https://doi.org/10.1016/j.ympev.2009.11.010

Ottenburghs J, Megens H-J, Kraus RHS, Madsen O, van Hooft P, van Wieren SE, Crooijmans RPMA, Ydenberg RC, Groenen MAM, Prins HHT (2016) A tree of geese: a phylogenomic perspective on the evolutionary history of true geese. Mol Phylogenet Evol 101:303-313. https://doi.org/10.1016/j.ympev.2016.05.021

Päckert M, Martens J, Wink M, Feigl A, Tietze DT (2012) Molecular phylogeny of Old World swifts (Aves: Apodiformes, Apodidae, Apus and Tachymarptis) based on mitochondrial and nuclear markers. Mol Phylogenet Evol 63:606-616. https://doi.org/10.1016/j.ympev.2012.02.002

Padial JM, de la Riva I (2007) Integrative taxonomists should use and produce DNA barcodes. Zootaxa 1586:67-68

Padial JM, Miralles A, De la Riva I, Vences M (2010) The integrative future of taxonomy. Front Zool 7:16. https://doi.org/10.1186/1742-9994-7-16 [a good review of integrative taxonomy]

Parkin DT, Collinson M, Helbig AJ, Knox AG, Sangster G (2003) The taxonomic status of Carrion and Hooded Crows. Br Birds 96:274-290

Paxinos EE, James HF, Olson SL, Sorenson MD, Jackson J, Fleischer RC (2002) mtDNA from fossils reveals a radiation of Hawaiian geese recently derived from the Canada Goose (Branta canadensis). Proc Natl Acad Sci U S A 99:1399-1404. https://doi.org/10.1073/pnas.032166399

Penhallurick J, Wink M (2004) Analysis of the taxonomy and nomenclature of the Procellariiformes based on complete nucleotide sequences of the mitochondrial cytochrome b gene. Emu 104:125-147

Pérez-Emán JL, Ferreira JP, Gutiérrez-Pinto N, Cuervo AM, Céspedes LN, Witt CC, Cadena CD (2018) An extinct hummingbird species that never was: a cautionary tale about sampling issues in molecular phylogenetics. Zootaxa 4442:491-497

Peters JL, McCracken KG, Pruett CL, Rohwer S, Drovetski SV, Zhuravlev YN, Kulikova I, Gibson DD, Winker K (2012) A parapatric propensity for breeding precludes the completion of speciation in common teal (Anas crecca, sensu lato). Mol Ecol 21:4563-4577. https://doi.org/ 10.1111/j.1365-294X.2012.05711.X 
Pianka ER (1966) Latitudinal gradients in species diversity: a review of concepts. Am Nat 100:33-46. https://doi.org/10.1086/282398

Pigliucci M, Kaplan J (2006) Making sense of evolution: the conceptual foundations of evolutionary biology. University Chicago Press, Chicago

Poelstra JW, Vijay N, Bossu CM, Lantz H, Ryll B, Müller I, Baglione V, Unneberg P, Wikelski M, Grabherr MG, Wolf JBW (2014) The genomic landscape underlying phenotypic integrity in the face of gene flow in crows. Science 344:1410-1414. https://doi.org/10.1126/science.1253226

Pons J-M, Thibault J-C, Aymí R, Grussu M, Muntaner J, Olioso G, Sunyer JR, Touihri M, Fuchs J (2016) The role of western Mediterranean islands in the evolutionary diversification of the Spotted Flycatcher (Muscicapa striata), a long-distance migratory passerine species. J Avian Biol 47:386-398. https://doi.org/10.1111/jav.00859

Rahbek C, Graves GR (2001) Multiscale assessment of patterns of avian species richness. Proc Natl Acad Sci U S A 98:4534-4539. https://doi.org/10.1073/pnas.071034898

Rasmussen PC, Schulenberg TS, Hawkins F, Voninavoko R (2000) Geographic variation in the Malagasy Scops-Owl (Otus rutilus auct.): the existence of an unrecognised species on Madagascar and the taxonomy of other Indian Ocean taxa. Bull Br Ornithol Club 120:75-102

Rawlence NJ, Kennedy M, Scofield RP, Tennyson AJD, Boussès P, Chambers GK (2015) Taxonomic status of Cyanoramphus parakeets on the Auckland Islands and implications for the validity of the orange-fronted parakeet as a discrete species. J R Soc N Z 45:197-211. https://doi.org/10.1080/ 03036758.2015.1084337

Reydon TAC (2004) Why does the species problem still persist? BioEssays 26:300-305. https://doi.org/ 10.1002/bies.10406

Ribas CC, Aleixo A, Nogueira ACR, Miyaki CY, Cracraft J (2011) A palaeobiogeographic model for biotic diversification within Amazonia over the past three million years. Proc R Soc B 279:681-689. https://doi.org/10.1098/rspb.2011.1120

Ridley M (1989) The cladistic solution to the species problem. Biol Philos 4:1-16. https://doi.org/ 10.1007/BF00144036

Robertson BC, Stephenson BM, Goldstien SJ (2011) When rediscovery is not enough: taxonomic uncertainty hinders conservation of a critically endangered bird. Mol Phylogenet Evol 61:949-952. https://doi.org/10.1016/j.ympev.2011.08.001

Ruokonen M, Litvin K, Aarvak T (2008) Taxonomy of the bean goose-pink-footed goose. Mol Phylogenet Evol 48:554-562. https://doi.org/10.1016/j.ympev.2008.04.038

Ruse M (1969) Definitions of species in biology. Br J Philos Sci 20:97-119

Sangster G (2000) Genetic distance as a test of species boundaries in the Citril Finch Serinus citrinella: a critique and taxonomic reinterpretation. Ibis 142:487-490. https://doi.org/10.1111/ j.1474-919X.2000.tb04447.x

Sangster G (2009) Increasing numbers of bird species result from taxonomic progress, not taxonomic inflation. Proc R Soc B 276:3185-3191. https://doi.org/10.1098/rspb.2009.0582

Sangster G (2014) The application of species criteria in avian taxonomy and its implications for the debate over species concepts. Biol Rev 89:199-214. https://doi.org/10.1111/brv.12051 [a detailed analysis of how bird species are delimited in practice]

Sangster G, Luksenburg JA (2015) Declining rates of species described per taxonomist: slowdown of progress or a side-effect of improved quality in taxonomy? Syst Biol 64:144-151. https://doi. org/10.1093/sysbio/syu069

Sangster G, Oreel GJ (1996) Progress in taxonomy of Taiga and Tundra Bean Geese. Dutch Birding 18:310-316

Sangster G, Collinson JM, Helbig AJ, Knox AG, Parkin DT, Prater T (2001) The taxonomic status of Green-winged Teal Anas carolinensis. Br Birds 94:218-224

Sangster G, Collinson JM, Helbig AJ, Knox AG, Parkin DT (2002) The specific status of Balearic and Yelkouan Shearwaters. Br Birds 95:636-639

Sangster G, Collinson JM, Crochet P-A, Kirwan GM, Knox AG, Parkin DT, Votier SC (2015) Taxonomic recommendations for Western Palaearctic birds: 10th report. Ibis 157:193-200. https://doi.org/10.1111/ibi.12221 
Sangster G, Roselaar CS, Irestedt M, Ericson PGP (2016a) Sillem's Mountain Finch Leucosticte sillemi is a valid species of rosefinch (Carpodacus, Fringillidae). Ibis 158:184-189. https://doi. org/10.1111/ibi.12323

Sangster G, Rodríguez-Godoy F, Roselaar CS, Robb MA, Luksenburg JA (2016b) Integrative taxonomy reveals Europe's rarest songbird species, the Gran Canaria Blue Chaffinch Fringilla polatzeki. J Avian Biol 47:159-166. https://doi.org/10.1111/jav.00825

Schlick-Steiner BC, Steiner FM, Seifert B, Stauffer C, Christian E, Crozier RH (2010) Integrative taxonomy: a multisource approach to exploring biodiversity. Annu Rev Entomol 55:421-438. https://doi.org/10.1146/annurev-ento-112408-085432

Schweizer M, Shirihai H (2013) Phylogeny of the Oenanthe lugens complex (Aves, Muscicapidae: Saxicolinae): paraphyly of a morphologically cohesive group within a recent radiation of openhabitat chats. Mol Phylogenet Evol 69:450-461. https://doi.org/10.1016/j.ympev.2013.08.010

Sharpe RB (1909) A hand-list of the genera and species of birds, vol 5. British Museum, London

Shaw AB (1969) Adam and Eve, paleontology, and the non-objective arts. J Paleontol 43:1085-1098

Shirihai H, Gargallo G, Helbig AJ, Harris A, Cottridge D (2001) Sylvia warblers: identification, taxonomy and phylogeny of the genus Sylvia. Helm, London

Simpson GG (1951) The species concept. Evolution 5:285-298. https://doi.org/10.1111/j.15585646.1951.tb02788.x

Sluys R (2013) The unappreciated, fundamentally analytical nature of taxonomy and the implications for the inventory of biodiversity. Biodivers Conserv 22:1095-1105. https://doi.org/10. 1007/s10531-013-0472-x

Smith AL, Monteiro L, Hasegawa O, Friesen VL (2007) Global phylogeography of the Band-rumped Storm-petrel (Oceanodroma castro; Procellariiformes: Hydrobatidae). Mol Phylogenet Evol 43:755-773. https://doi.org/10.1016/j.ympev.2007.02.012

Sober E (ed) (2006) Conceptual issues in evolutionary biology, 3rd edn. MIT Press, Cambridge

Sokal RR, Crovello TJ (1970) The biological species concept: a critical evaluation. Am Nat 104:127-153. https://doi.org/10.1086/282646

Stamos DN (2003) The species problem: biological species, ontology, and the metaphysics of biology. Lexington Books, Lanham

Stattersfield AJ, Crosby MJ, Long AJ, Wege DC (1998) Endemic bird areas of the World. Birdlife Conservation Series 7, Birdlife International, Cambridge

Stejneger L (1884) On the use of trinomials in American ornithology. Proc US Natl Mus 7:70-80

Stone W (1899) The proper function of 'binomials' and 'trinomials'. Auk 16:374-376. https://doi. org/10.2307/4069392

Swenson NG (2010) Mapping the suturing of a continental biota. Mol Ecol 19:5324-5327. https://doi. org/10.1111/j.1365-294x.2010.04880.x

Tobias JA, Bates JM, Hackett SJ, Seddon N (2008) Comment on "The Latitudinal Gradient in Recent Speciation and Extinction Rates of Birds and Mammals". Science 319:901c. https://doi. org/10.1126/science. 1150568

Tobias JA, Seddon N, Spottiswoode CN, Pilgrim JD, Fishpool LDC, Collar NJ (2010) Quantitative criteria for species delimitation. Ibis 152:724-746. https://doi.org/10.1111/j.1474-919x.2010. 01051.x

Trier CN, Hermansen JS, Sætre G-P, Bailey RI (2014) Evidence for mito-nuclear and sex-linked reproductive barriers between the hybrid Italian Sparrow and its parent species. PLoS Genet 10: e1004075. https://doi.org/10.1371/journal.pgen.1004075

Van Valen L (1976) Ecological species, multispecies, and oaks. Taxon 25:233-239. https://doi.org/ $10.2307 / 1219444$

Vane-Wright RI, Humphries CJ, Williams PH (1991) What to protect? Systematics and the agony of choice. Biol Conserv 55:235-254. https://doi.org/10.1016/0006-3207(91)90030-D

Voelker G, Marks BD, Kahindo C, A'genonga U, Bapeamoni F, Duffie LE, Huntley JW, Mulotwa E, Rosenbaum SA, Light JE (2013) River barriers and cryptic biodiversity in an evolutionary museum. Ecol Evol 3:536-545. https://doi.org/10.1002/ece3.482

Weir JT, Schluter D (2007) The latitudinal gradient in recent speciation and extinction rates of birds and mammals. Science 315:1574-1576. https://doi.org/10.1126/science.1135590 
Wheeler QD, Cracraft J (1997) Taxonomic preparedness: are we ready to meet the biodiversity challenge? In: Reaka-Kudla ML, Wilson DE, Wilson EO (eds) Biodiversity II. Joseph Henry Press, Washington, pp 435-446

Whitney BM, Alvarez Alonso J (1998) A new Herpsilochmus antwren (Aves: Thamnophilidae) from northern Amazonian Peru and adjacent Ecuador: the role of edaphic heterogeneity of terra firme forest. Auk 115:559-576. https://doi.org/10.2307/4089406

Whitney BM, Alvarez Alonso J (2005) A new species of gnatcatcher from white-sand forests of northern Amazonian Peru with revision of the Polioptila guianensis complex. Wilson Bull 117:113-127. https://doi.org/10.1676/04-064

Wiens JJ, Servedio MR (2000) Species delimitation in systematics: inferring diagnostic differences between species. Proc R Soc Lond B 267:631-636. https://doi.org/10.1098/rspb.2000.1049

Wiley EO (1978) The evolutionary species concept reconsidered. Syst Zool 27:17-26. https://doi. org/10.2307/2412809

Will KW, Mishler BD, Wheeler QD (2005) The perils of DNA barcoding and the need for integrative taxonomy. Syst Biol 54:844-851. https://doi.org/10.1080/10635150500354878

Willig MR, Kaufman DM, Stevens RD (2003) Latitudinal gradients of biodiversity: pattern, process, scale, and synthesis. Annu Rev Ecol Evol Syst 34:273-309. https://doi.org/10.1146/ annurev.ecolsys.34.012103.144032

Wilson BE (1995) A (not-so-radical) solution to the species problem. Biol Philos 10:339-356. https://doi.org/10.1007/BF00852472

Wolf JBW, Bayer T, Haubold B, Schilhabel M, Rosenstiel P, Tautz D (2010) Nucleotide divergence vs. gene expression differentiation: comparative transcriptome sequencing in natural isolates from the carrion crow and its hybrid zone with the hooded crow. Mol Ecol 19(Suppl 1):162-175. https://doi.org/10.1111/j.1365-294X.2009.04471.x

Yeates DK, Seago A, Nelson L, Cameron SL, Joseph L, Trueman JW (2011) Integrative taxonomy, or iterative taxonomy? Syst Entomol 36:209-217. https://doi.org/10.1111/j.1365-3113.2010.00558.x

\section{Suggestion for Further Reading}

Ereshefsky M (ed) (1992) The units of evolution. MIT Press, Cambridge [a collection of classic papers in the debate over species concepts, written by biologists and philosophers of science]

Open Access This chapter is licensed under the terms of the Creative Commons Attribution 4.0 International License (http://creativecommons.org/licenses/by/4.0/), which permits use, sharing, adaptation, distribution and reproduction in any medium or format, as long as you give appropriate credit to the original author(s) and the source, provide a link to the Creative Commons license and indicate if changes were made.

The images or other third party material in this chapter are included in the chapter's Creative Commons license, unless indicated otherwise in a credit line to the material. If material is not included in the chapter's Creative Commons license and your intended use is not permitted by statutory regulation or exceeds the permitted use, you will need to obtain permission directly from the copyright holder.

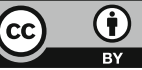

